\title{
Relevance of Allergenic Sensitization to Cynodon dactylon and Phragmites communis: Cross-reactivity With Pooideae Grasses
}

\author{
López-Matas MA' ${ }^{1}$, Moya $R^{1}$, Cardona $V^{2}$, Valero $A^{3}$, Gaig $P^{4}$, Malet $A^{5}$, Viñas $M^{6}$, \\ García-Moral $\mathrm{A}^{3}$, Labrador $\mathrm{M}^{2}$, Alcoceba $\mathrm{E}^{7}$, Ibero $\mathrm{M}^{6}$, Carnés $\mathrm{J}^{1}$
}

${ }^{1}$ RCtD Department, Laboratorios LETI S.L.U., Tres Cantos, Madrid, Spain

${ }^{2}$ Allergy Unit, Hospital General de la Vall d'Hebron, Barcelona, Spain

${ }^{3}$ Allergy Unit, Hospital Clínic de Barcelona, Barcelona, Spain

${ }^{4}$ Allergy Unit, Hospital Universitari Joan XXIII, Tarragona, Spain

${ }^{5}$ Allergo Centre, S.L.P., Barcelona, Spain

${ }^{6}$ Allergy Unit, Hospital de Terrassa, Barcelona, Spain

${ }^{7}$ Allergy Unit, Hospital Arnau de Vilanova, Lleida, Spain

J Investig Allergol Clin Immunol 2016; Vol. 26(5): 295-303

doi: 10.18176/jiaci.0049

\begin{abstract}
Background and Objectives: The homologous group of sweet grasses belongs to the Pooideae subfamily, but grass pollen species from other subfamilies can also cause allergy, such as Cynodon dactylon (Chloridoideae) and Phragmites communis (Arundinoideae). C dactylon and $P$ communis have not been included in the sweet grasses homologous group because of their low cross-reactivity with other grasses. The aims of this study were to investigate the profile of sensitization to $C$ dactylon and $P$ communis in patients sensitized to grasses and to analyze cross-reactivity between these 2 species and temperate grasses.

Methods: Patients were skin prick tested with a grass mixture (GM). Specific lgE to GM, C dactylon, P communis, Cyn d 1, and Phl p 1 was measured by ImmunoCAP. A pool of sera was used for the immunoblot assays. Cross-reactivity was studied by ELISA and immunoblot inhibition. Results: Thirty patients had slgE to GM. Twenty-four (80\%) had positive results for $C$ dactylon, 27 (90\%) for $P$ communis, 22 (73.3\%) for nCyn d 1, and $92.9 \%$ for rPhl p 1. Bands were detected in the 3 extracts by immunoblot. Inhibition of GM was not observed with $C$ dactylon or $P$ communis by immunoblot or ELISA inhibition. When $C$ dactylon or $P$ communis were used in the solid phase, GM produced almost complete inhibition.

Conclusions: Eighty percent of patients sensitized to grasses were also sensitized to $C$ dactylon and $90 \%$ were sensitized to $P$ communis. Sensitization to these species seems to be induced by allergens different to those in sweet grasses.
\end{abstract}

Key words: Grass allergy. Cross-reactivity. Cynodon dactylon. Phragmites communis. Phl p 1. Cyn d 1.

\section{Resumen}

Antecedentes y Objetivos: Desde un punto de vista taxonómico, el grupo homólogo de las gramíneas pertenece a la sub-familia Pooideae. Sin embargo, existen también otras especies de gramíneas alergénicas que pertenecen a sub-familias diferentes como son Cynodon dactylon (Chloridoideae) o Phragmites communis (Arundinoideae). C. dactylon y P. communis no están incluidas en este grupo homólogo debido a que la reactividad cruzada con otras gramíneas es limitada. Los objetivos del estudio fueron investigar el perfil de sensibilización a $C$. dactylon y $P$. communis en pacientes sensibilizados a gramíneas y analizar la reactividad cruzada entre estas dos especies y las gramíneas más comunes.

Métodos: A los pacientes se les realizó una prueba cutánea con una mezcla de gramíneas (MG). Mediante ImmunoCAP se midió la lgE específica para MG, C. dactylon, P. communis, Cyn d 1 y Phl p 1. Un pool de sueros se utilizó para ensayos de inmunoblot. La reactividad cruzada se estudió mediante ELISA e inmunoblot inhibición. 
Resultados: Treinta pacientes tuvieron IgE específica para MG. Veinticuatro (80\%) fueron positivos a C. dactylon, 27 (90\%) a P. communis, $22(73,3 \%)$ a nCyn d 1 y 92,9\% fueron positivos a rPhl p 1. Se detectaron bandas en los tres extractos mediante inmunoblot. No se observó inhibición de MG con las otras dos especies mediante inmunoblot o ELISA inhibición. Cuando C. dactylon o P. communis se usaron en fase sólida, MG produjo una inhibición casi completa.

Conclusiones: El $80 \%$ de los pacientes sensibilizados a gramíneas estaban también sensibilizados a C. dactylon y el $90 \%$ a $P$. communis. La sensibilización a estas especies parece estar inducida por diferentes alérgenos que en el caso de gramíneas.

Palabras clave: Alergia a gramíneas. Reactividad cruzada. Cynodon dactylon. Phragmites communis. Phl p 1. Cyn d 1.

\section{Introduction}

Grasses, and particularly species from the Poaceae family, are the main cause of pollen allergy worldwide. The Poaceae family has different subfamilies, of which the temperate Pooideae subfamily contains the most allergenic species. However, there are other subfamilies with species capable of inducing allergic symptoms, such as Chloridoideae (Cynodon dactylon) and Arundinoideae (Phragmites communis). Both $C$ dactylon and $P$ communis have been identified in warm temperate and subtropical areas in Africa, Asia, Australia, and America [1], and also in Europe up to a latitude of approximately $53^{\circ} \mathrm{N}$ [2]. Although $C$ dactylon is now cosmopolitan, it is generally recognized that its present distribution is largely due to human activities [3] as it is used as livestock herbage and turf. In recent years, climate change has contributed to modifications in pollen release and distribution patterns, and different species are colonizing new areas, modifying the allergenic composition of the environment. In countries with temperate climates such as Spain [4,5] and Italy [6], Pooideae and subtropical grasses coexist in the same areas. In Spain, $C$ dactylon is found throughout the country, while $P$ communis is more frequent in humid areas such as coastal regions and close to rivers [7].

Pollen grains from different grass families have a similar morphology and it is very difficult to distinguish them by visual inspection. Studies of flowering may help to identify specific grasses responsible for pollen allergy by identifying the pollination season of different species [8]. C dactylon has been found to flower later than temperate grasses [6], possibly explaining the onset of symptoms in grass-sensitized patients in late June or July. Patterns of sensitization depend on primary grass sensitization and differ from one geographic region to the next [1].

To date, species of the Pooideae family have been grouped in the same homologous group: the sweet grasses. Membership of this group is based on the presence of 3 allergen families: group 1, 2, and 5 [9]. Cross-reactivity studies with different species have shown that the majority of Pooideae species are highly cross-reactive [10-12]. C dactylon is not included in this homologous group because it shows limited cross-reactivity with other grasses [9]. There have, however, been recent calls for the inclusion of $C$ dactylon in this group, but considering only the allergen Cyn d 1 [13]. Seven allergens have been described to date in C dactylon: Cyn d 1, Cyn d 7, Cyn d 12, Cyn d 15, Cyn d 22w, Cyn d 23, and Cyn d 24 (IUIS Allergen Nomenclature Subcommittee) [14], although an additional
8 allergens (Cyn d 2, Cyn d 3, Cyn d 5, Cyn d 6, Cyn d 11, Cyn d 13, Cyn d CP, and Cyn d EXI) have been reported in Allergome.org [15]. Several publications have described the lack of group 2 and 5 allergens in $C$ dactylon [16], although they are mentioned in Allergome. Only Cyn d 1 and Cyn d 7 have been found to exhibit some cross-reactivity with other grasses, but the results are not consistent [9]. Moreover, group 1 allergens in $C$ dactylon have different epitopes to group 1 allergens in Pooideae grasses $[1,17]$. These differences are probably responsible for the low cross-reactivity between $C$ dactylon and members of the Pooideae subfamily $[1,18]$.

Five allergens have been described in $P$ communis: Phra 1, Phra 4, Phr a 5, Phr a 12, and Phra 13, (Allergome database) [15]. There are reports of a lack of group 2 and 6 allergens in $P$ communis [19] and of low cross-reactivity with grasses from the Pooideae family [20]. P communis has been insufficiently studied to be considered for inclusion in the homologous group of sweet grasses.

The aims of the study were to investigate profiles of sensitization to $C$ dactylon and $P$ communis in patients sensitized to grasses in Catalonia (northeast Spain) and to analyze cross-reactivity between these 2 species and a mixture of temperate grasses.

\section{Materials and Methods}

\section{Patient Population}

Patients were recruited from 6 hospitals in the northeast of Spain: Hospital Universitari Joan XXIII (Tarragona), Allergo Center (Barcelona), Hospital de Terrassa (Terrassa, Barcelona), Hospital Clinic (Barcelona), Hospital Vall d'Hebron (Barcelona), and Hospital Arnau de Vilanova (Lleida). The selection criteria were the presence of respiratory symptoms (rhinitis and/or asthma) during the grass pollen season and a positive skin prick test (wheal diameter $>3 \mathrm{~mm}$ ) with a standardized grass mixture (GM) containing equal amounts of Dactylis glomerata, Festuca elatior, Lolium perenne, Phleum pratense, and Poa pratensis (Laboratorios LETI S.L.U., Tres Cantos, Madrid, Spain). A serum sample was obtained after oral consent from each of the patients enrolled in the study.

All patients were also skin prick tested with a battery of biologically standardized aeroallergens including pollens (Olea europaea, Artemisia vulgaris, Parietaria judaica, Cupressus arizonica, Salsola kali, Platanus acerifolia, and Plantago lanceolata) as well as mites, molds, and epithelia. 


\section{Extract Preparation}

Pollen extracts were prepared following internal manufacturing procedures (Laboratorios LETI). Briefly, grass pollen ( $D$ glomerata, $F$ elatior, L perenne, $P$ pratense, $P$ pratensis, $C$ dactylon, and $P$ communis) was extracted consecutively for 4 and 8 hours in phosphate-buffered saline (PBS) $0.01 \mathrm{M}, \mathrm{pH}$ 7.4. After each extraction the sample was centrifuged and the supernatant recovered. Supernatants from both extractions were pooled, filtered, and freeze dried. The protein content was measured using the Bradford method (Thermo Fisher Scientific).

\section{SDS-PAGE and 2-D Electrophoresis}

SDS-PAGE analysis was used to determine the protein profile of the grass extracts. Fifty micrograms of protein from every extract were loaded. Bands were analyzed via densitometry with the ImageQuant TL 8.1 software (GE Healthcare).

For 2-D electrophoresis, the extracts were purified and concentrated with a solution of ammonium sulfate in 2 separate steps until the saturation percentages of $40 \%$ and $80 \%$ were reached; they were then stored at $4^{\circ} \mathrm{C}$ overnight. Thereafter, the samples were centrifuged and the pellets were collected and reconstituted in ultrapure water. Concentrated extracts were washed using the ReadyPrep 2-D Cleanup Kit (BioRad) following the manufacturer's instructions. Proteins were separated according to their isoelectric point on ReadyStrip IPG strips (BioRad) with a $\mathrm{pH}$ range of 3 to 10, using Protean IEF Cell (BioRad). After the first dimension, the strips were equilibrated with ReadyPrep 2-D Kit buffers (BioRad) and proteins were separated in the second dimension according to their molecular weight. Gels were stained with Oriole fluorescent solution (BioRad) following the manufacturer's instructions.

\section{Specific IgE}

Specific IgE to GM, $C$ dactylon, $P$ communis, and the allergens Phl p 1 and Cyn d 1 was determined for all serum samples by ImmunoCAP (Thermo Fisher Scientific) following the manufacturer's instructions. A specific $\operatorname{IgE}$ (sIgE) of over $0.35 \mathrm{kUA} / \mathrm{L}$ was considered positive.

\section{ELISA Assays}

Direct ELISA was performed with a pool of sera prepared by mixing equal quantities of sera with an $\operatorname{sgE}$ to the GM of over $1 \mathrm{kUA} / \mathrm{L}$ (27 sera). Briefly, a microplate (Immulon 4HBX, Thermo Fisher Scientific) was coated with $20 \mu \mathrm{g}$ of lyophilized extract per milliliter, and the pool of sera $(1: 1$ diluted in $0.01 \mathrm{M}$ PBS) was incubated for 2 hours at room temperature. After 3 washes, peroxidase-conjugated monoclonal anti-human IgE (Ingenasa, Madrid, Spain) was added. Two hours later, the reaction was developed, stopped, and read at $450 \mathrm{~nm}$. Results were expressed in optical density units. ELISA inhibition was performed with the pool of sera as well as with individual sera. For the inhibition assay, sera were preincubated with the inhibitory extract for 2 hours before the addition to the microplate.

\section{Immunoblot Experiments}

Fifty micrograms of protein of each extract were electrophoresed by SDS-PAGE and electrotransferred to a Trans Blot Turbo Transfer Pack (BioRad). Membranes were incubated overnight with the pool of sera (dilution $1 / 5$ in 0.01 M PBS Tween 0.1\%). After washing, membranes were incubated with anti-human IgE-PO (Ingenasa), developed with luminol solutions (Immun-Star HRP Chemiluminescent Kit, BioRad) and detected by chemiluminescence (ChemiDoc XRS, Bio-Rad). The same procedure was used for the immunoblot inhibition experiments; in this case the pool of sera was incubated for 2 hours at room temperature with $500 \mu \mathrm{g}$ of the inhibitory extract before its addition to the blot membrane.

\section{Quantification of Group 5 Allergens}

Group 5 allergens were quantified in the 3 extracts. Briefly, microplates (MaxiSorp; Thermo Scientific) were coated with MA-1D11 anti-Phl p 5 monoclonal antibody (Indoor Biotechnologies) at a dilution 1/1000. After blocking with $1 \%$ BSA, PBS-Tween $0.05 \%$, the samples were added to the plate in serial dilutions from $1 \mu \mathrm{g} / \mathrm{mL}$ to $31.25 \mathrm{ng} / \mathrm{mL}$. The European Pharmacopoeia Reference Standard (EDQM) was used as a standard. After an hour of incubation, the biotinylated anti-Phl p 5 mAb Bol (Indoor Biotechnologies) was added and incubated for 1 hour. Finally, streptavidin-PO was added and the reaction was developed and measured at $450 \mathrm{~nm}$.

\section{Statistical Analysis}

Descriptive statistical analyses were used for the calculation of variables and the Mann-Whitney rank sum Test was used to compare sIgE values. The relationship between sIgE values was compared by linear regression. SigmaStat 3.5 software (Point Richmond, California, USA) was used for the statistical analysis.

\section{Results}

\section{Patient Population}

Thirty-one patients were recruited (Table 1). They all had rhinitis; 20 had conjunctivitis $(64.5 \%), 6$ had asthma (19.4\%), and 6 had cutaneous symptoms (19.4\%). Only 3 individuals (9.7\%) were monosensitized to grass pollen, 24 (77.4\%) were sensitized to other pollen extracts, mainly olive tree pollen (19 patients, $61.3 \%$ ), 16 were sensitized to mites (51.6\%), and 12 were sensitized to animal dander (38.7\%).

\section{SDS-PAGE and 2-D electrophoresis}

In SDS-PAGE, the 3 extracts (GM, $C$ dactylon, and $P$ communis) showed protein bands with a molecular weight in the range of 10 to $100 \mathrm{kDa}$. The densitometry assay showed a very similar profile for the 3 extracts (Figure 1A). The most intense bands were at 10 and $13 \mathrm{kDa}$ for the GM extract and at $34 \mathrm{kDa}$ for the $C$ dactylon and $P$ communis extracts (Figure 1). In 2-D electrophoresis, we observed that most proteins in the 3 extracts were located in the acidic region (left middle part of the gel) and had different isoforms (Figure 1B). Some spots 
Table 1. Characteristics of the Study Population

\begin{tabular}{|c|c|c|c|c|c|c|c|c|c|}
\hline \multirow[b]{2}{*}{ No. } & \multirow[b]{2}{*}{ Age, y } & \multirow[b]{2}{*}{ Sex } & \multicolumn{5}{|c|}{$\operatorname{IgE}(\mathrm{kUA} / \mathrm{L})$} & \multirow[b]{2}{*}{ Symptoms } & \multirow[b]{2}{*}{$\begin{array}{c}\text { Other } \\
\text { Sensitizations }\end{array}$} \\
\hline & & & GM & Phl p 1 & Cyn & Cyn d 1 & Phr & & \\
\hline 1 & 32 & $\mathrm{M}$ & 8.14 & 8.82 & 1.52 & 2.44 & 0.84 & $\mathrm{R}, \mathrm{C}$ & \\
\hline 2 & 44 & $\mathrm{~F}$ & 3.53 & 0.94 & $\mathrm{Neg}$ & 0.51 & 0.4 & $\mathrm{R}, \mathrm{C}$ & \\
\hline 3 & 34 & $\mathrm{~F}$ & 6.86 & 4.91 & 1.3 & 2.26 & 2.9 & $\mathrm{R}, \mathrm{C}, \mathrm{S}$ & P, Mi, D \\
\hline 4 & 40 & $\mathrm{~F}$ & 1.94 & Neg & 3.51 & Neg & 4.05 & $\mathrm{R}, \mathrm{C}, \mathrm{S}$ & P, Mi, D \\
\hline 5 & 50 & M & 4.22 & 3.43 & 1.1 & 2.15 & 1.83 & $\mathrm{R}, \mathrm{C}, \mathrm{A}$ & $\mathrm{P}$ \\
\hline 6 & 23 & $\mathrm{~F}$ & $>100$ & NA & 21.4 & 65.8 & $>100$ & $\mathrm{R}, \mathrm{A}$ & Mi, D \\
\hline 7 & 19 & M & $>100$ & NA & 6.82 & 33.4 & 55.4 & $\mathrm{R}$ & P, Mi, D \\
\hline 8 & 25 & M & 24.9 & $\mathrm{Neg}$ & $\mathrm{Neg}$ & Neg & 2.53 & $\mathrm{R}$ & $\mathrm{P}$ \\
\hline 9 & 52 & M & 21.8 & 2.3 & 5.43 & 2.51 & 6.34 & $\mathrm{R}$ & $\mathrm{P}$ \\
\hline 10 & 9 & M & $>100$ & $>100$ & 6.77 & 62.2 & 48.7 & $\mathrm{R}$ & Mi \\
\hline 11 & 37 & M & 29.6 & 10.3 & 1.11 & 0.4 & 3.32 & $\mathrm{R}, \mathrm{C}$ & $\mathrm{P}$ \\
\hline 12 & 29 & M & 1.55 & 14.2 & $\mathrm{Neg}$ & $\mathrm{Neg}$ & 0.58 & $\mathrm{R}, \mathrm{C}, \mathrm{S}$ & P, Mi, Fu, D \\
\hline 13 & 20 & $\mathrm{~F}$ & 84.5 & 92.9 & 28.3 & 17.6 & 32.1 & $\mathrm{R}, \mathrm{C}, \mathrm{S}$ & P, Mi, D \\
\hline 14 & 39 & $\mathrm{~F}$ & 14.1 & 17 & 1.46 & Neg & 1.77 & $\mathrm{R}, \mathrm{C}$ & Mi \\
\hline 15 & 36 & M & 1.23 & 2.04 & 0.45 & Neg & 0.61 & $\mathrm{R}, \mathrm{C}, \mathrm{A}$ & P, Mi, Fu, D \\
\hline 16 & 42 & $\mathrm{~F}$ & 3.16 & 4 & 1.14 & 0.93 & 1.14 & R & $\mathrm{P}$ \\
\hline 17 & 8 & M & 27.7 & 42 & 15.8 & 11.2 & 13.9 & $\mathrm{R}$ & $\mathrm{P}, \mathrm{D}$ \\
\hline 18 & 62 & $\mathrm{~F}$ & 2.82 & 0.99 & 0.62 & 1.66 & 1.56 & $\mathrm{R}, \mathrm{C}$ & $\mathrm{P}$ \\
\hline 19 & 27 & M & 0.82 & 0.79 & Neg & Neg & Neg & $\mathrm{R}, \mathrm{C}$ & $\mathrm{Mi}$ \\
\hline 20 & 60 & $\mathrm{~F}$ & 0.59 & 1.36 & $\mathrm{Neg}$ & $\mathrm{Neg}$ & Neg & $\mathrm{R}$ & \\
\hline 21 & 39 & $\mathrm{~F}$ & 66.6 & 23.2 & 10.4 & 18.2 & 16.7 & $\mathrm{R}, \mathrm{C}$ & P, Mi, D \\
\hline 22 & 27 & $\mathrm{~F}$ & 61.2 & 12.8 & 1.94 & 5.11 & 6.54 & $\mathrm{R}, \mathrm{C}$ & P, Mi, D \\
\hline 23 & 42 & $\mathrm{~F}$ & 2.38 & 1.32 & 0.43 & 0.7 & 0.49 & $\mathrm{R}, \mathrm{S}$ & P, Mi, D \\
\hline 24 & 36 & M & Neg & Neg & Neg & Neg & Neg & $\mathrm{R}, \mathrm{C}$ & $\mathrm{P}$ \\
\hline 25 & 39 & $\mathrm{~F}$ & 13.8 & 11.9 & 6.29 & 6.91 & 10.2 & $\mathrm{R}$ & $\mathrm{P}, \mathrm{Mi}$ \\
\hline 26 & 27 & $\mathrm{~F}$ & 0.43 & 0.61 & Neg & Neg & Neg & $\mathrm{R}, \mathrm{C}$ & $\mathrm{P}, \mathrm{Mi}$ \\
\hline 27 & 41 & M & 27.8 & 2,10 & 31.7 & 33.6 & 0.79 & $\mathrm{R}, \mathrm{C}, \mathrm{S}$ & $\mathrm{P}, \mathrm{Mi}, \mathrm{Fu}, \mathrm{D}$ \\
\hline 28 & 35 & $\mathrm{~F}$ & 0.46 & 3.35 & 0.63 & 0.66 & 4.56 & $\mathrm{R}, \mathrm{C}, \mathrm{A}$ & $\mathrm{P}$ \\
\hline 29 & 34 & M & 0.87 & 1.97 & 1.32 & 0.93 & 2.76 & R & $\mathrm{P}$ \\
\hline 30 & 40 & M & 1.94 & 7.58 & 2.27 & 3.6 & 7.73 & $\mathrm{R}, \mathrm{C}, \mathrm{A}$ & $\mathrm{P}$ \\
\hline 31 & 28 & $\mathrm{~F}$ & 1.73 & 30.4 & 2.51 & 5.08 & 36.6 & $\mathrm{R}, \mathrm{C}, \mathrm{A}$ & $\mathrm{P}$ \\
\hline
\end{tabular}

Abbreviations: A, asthma; C, conjunctivitis; Cyn, Cynodon dactylon; D, animal dander; F, female; Fu, fungi; GM, mixture of grasses; M, male, Mi, mites; NA, specific IgE not analyzed; Neg, negative (<0.35 kUA/L); P, other pollen; Phr, Phragmites communis; R, rhinitis; S, skin symptoms.

had a different intensity depending on the extract. There were, for instance, 2 intense spots around $21 \mathrm{kDa}$ in $C$ dactylon and $P$ communis that were unremarkable in the GM extract. Conversely, there was an intense spot at $10 \mathrm{kDa}$ in the GM extract that was less intense in the $C$ dactylon extract and not detected in the $P$ communis extract. These spots are Circled in Figure 1B. We also detected some characteristic spots for the $C$ dactylon and $P$ communis extracts (Surrounded by a square in Figure 1B). Other visible differences may be due to the specific method variations for the 3 gels.

\section{Specific IgE}

Positive specific IgE to GM was detected in 30 patients. One patient (\#24, see Table 1) had negative results to all the extracts and was not included in further assays. Twenty-four 

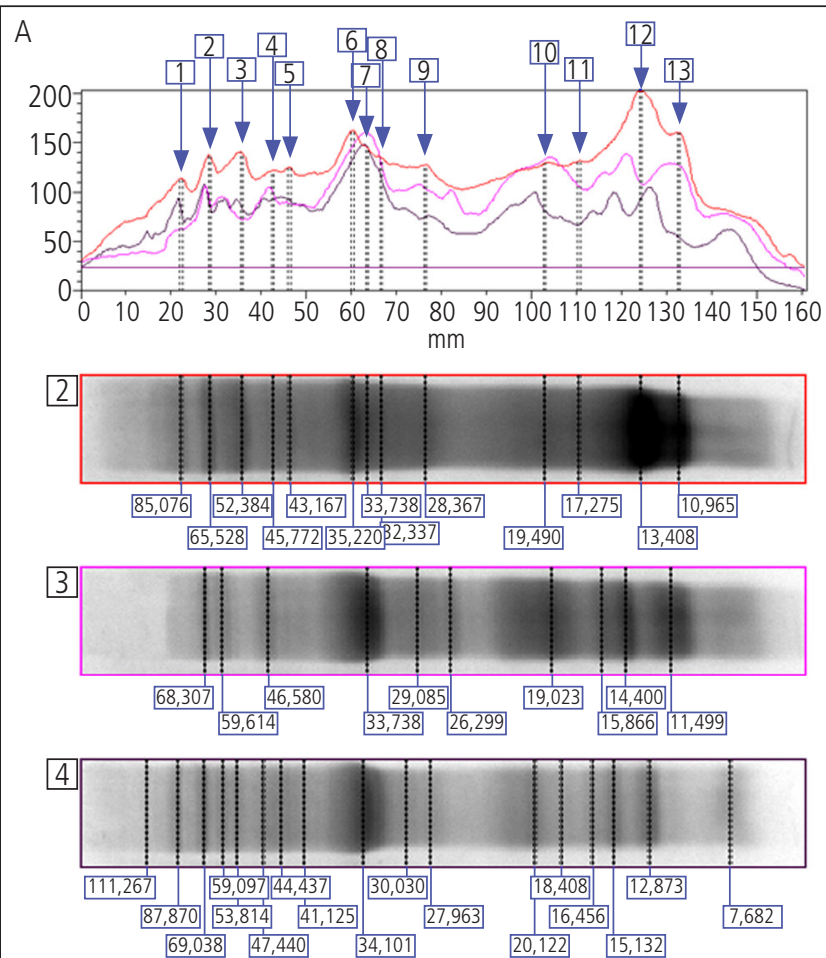

Figure 1. Protein profile. A, Scanning densitometry for the comparison of the profile of the 3 extracts. Red shows grass mix (GM), pink, Cynodon dactylon, and purple, Phragmites communis. B, 2-D electrophoresis for the 3 extracts. The SDS-PAGE results for each extract are shown next to each 2-D gel. Spots with different intensity in the extracts are marked in red, spots that appear in just 1 extract are marked in green.
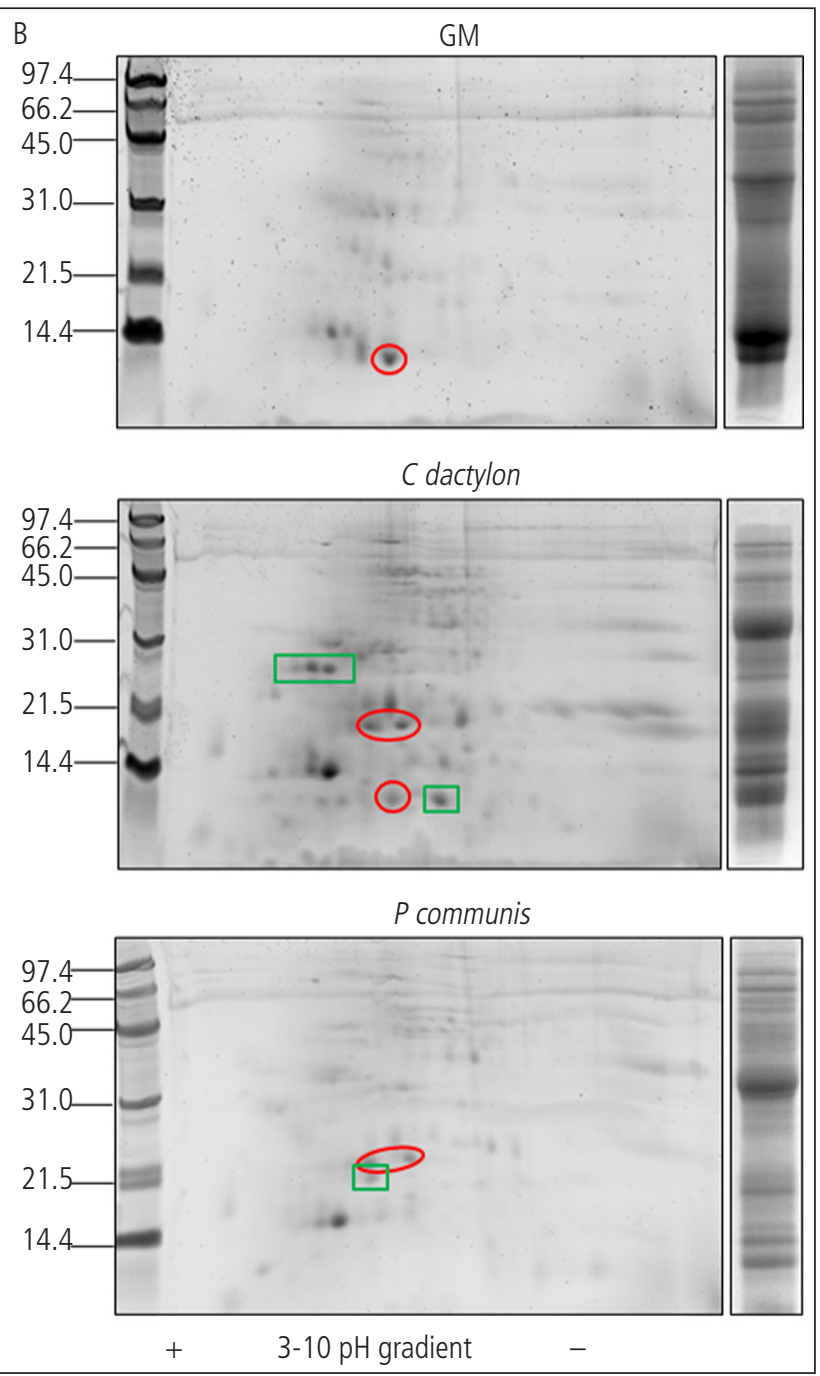

individuals (80\%) were positive to $C$ dactylon and 27 (90\%) to $P$ communis. The highest mean (SD) IgE values were obtained with GM $(23.8$ [33.4] kUA/L) and the lowest with $C$ dactylon (6.4 [8.9] kUA/L). There were no statistical significant differences between the values obtained for the different extracts (Figure 2). For the group 1 allergens, 26 individuals $(92.9 \%, 26 / 28)$ were positive to Phl p 1 (this test was not performed in 2 patients due to a lack of serum sample) and 22 (73.3\%) were positive to Cyn d 1 (Figure 2). In the regression analysis of sIgE values, we found the highest correlation between $P$ communis and $\mathrm{Phl} \mathrm{p} 1\left(\mathrm{R}^{2}=0.8\right)$. For $C$ dactylon, the correlation with all the other extracts was low (0.2-0.4). Correlation between Cyn d 1 and Phl p 1 was 0.5 (Figure 3).

\section{ELISA and ELISA Inhibition}

The pool of sera recognized the 3 extracts by direct ELISA. Values obtained with GM in the solid phase were 2 to 4.4 times higher than those obtained with $C$ dactylon and 1.3 to 2.4 times higher than with $P$ communis (Figure 4).
In the ELISA inhibition assay, $0.05 \mathrm{ng}$ of GM extract was necessary to obtain the $50 \%$ inhibition point, compared with 5.7 and $4.9 \mu \mathrm{g}$ for $C$ dactylon and $P$ communis, respectively. These assays were performed with GM in the solid phase. Valid inhibition lines were obtained only with 3 individual serum samples (serum 3, 6 and 17). To obtain the $50 \%$ inhibition point with $C$ dactylon compared with GM, the quantity needed was 650 times higher for serum 3, 353 times higher for serum 6, and 337 times higher for serum 17. The respective increases in quantity for $P$ communis were 3360 for serum 3, 436 for serum 6 , and 300 for serum 17. All the assays were performed with GM in the solid phase.

\section{Immunoblot Experiments}

The pool of sera recognized 2 main bands with a molecular weight of around $30 \mathrm{kDa}$ in the GM extract, 1 band in the $C$ dactylon extract, and 2 bands in the $P$ communis extract (Figure 5). 


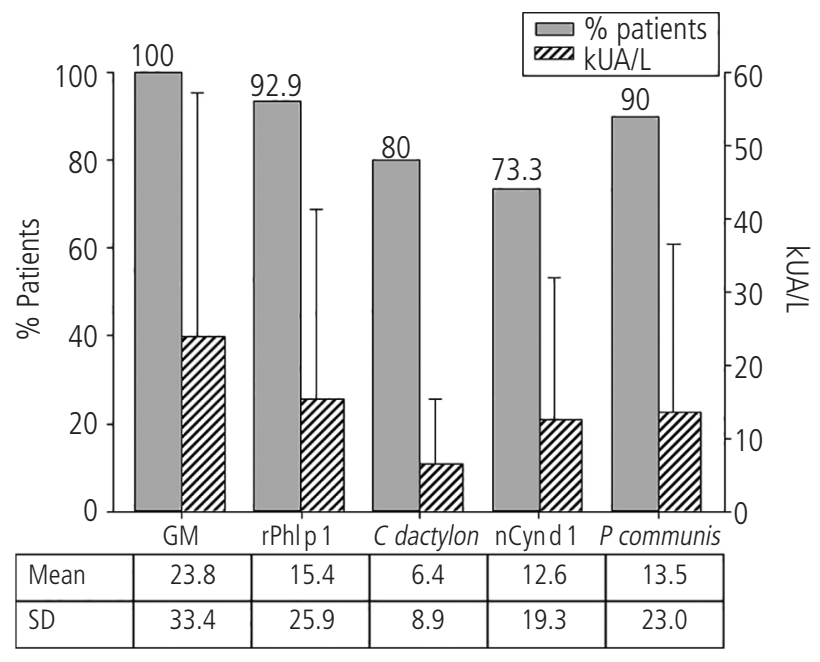

Figure 2. Percentage of patients sensitized to each extract and to the individual allergens and the mean value of slgE (KUA/L). Error bars correspond to SD. Mean values and SD are shown in the table below.

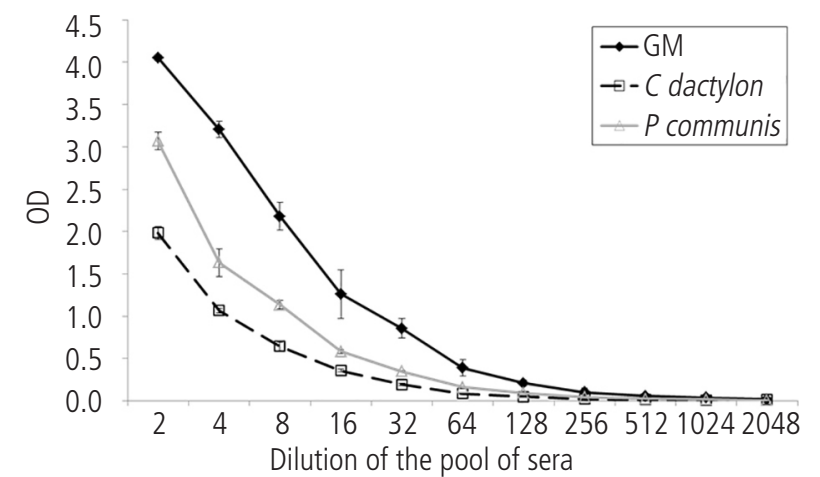

\begin{tabular}{|l|l|l|l|l|l|l|l|l|l|l|l|}
\hline GM & 4.05 & 3.21 & 2.18 & 1.26 & 0.86 & 0.39 & 0.21 & 0.10 & 0.06 & 0.04 & 0.02 \\
\hline
\end{tabular} \begin{tabular}{|l|l|l|l|l|l|l|l|l|l|l|l|}
\hline C dactylon & 1.98 & 1.07 & 0.64 & 0.36 & 0.19 & 0.09 & 0.05 & 0.02 & 0.01 & 0.01 & 0.01 \\
\hline
\end{tabular} \begin{tabular}{|l|l|l|l|l|l|l|l|l|l|l|l|}
\hline P communis & 3.07 & 1.63 & 1.13 & 0.59 & 0.35 & 0.16 & 0.09 & 0.05 & 0.03 & 0.02 & 0.01 \\
\hline
\end{tabular}

Figure 4. Direct ELISA with grass mix (GM), Cynodon dactylon, and Phragmites communis extracts in the solid phase and incubation with serial dilutions of the pool of sera. The specific optical density (OD) values are shown in the table.

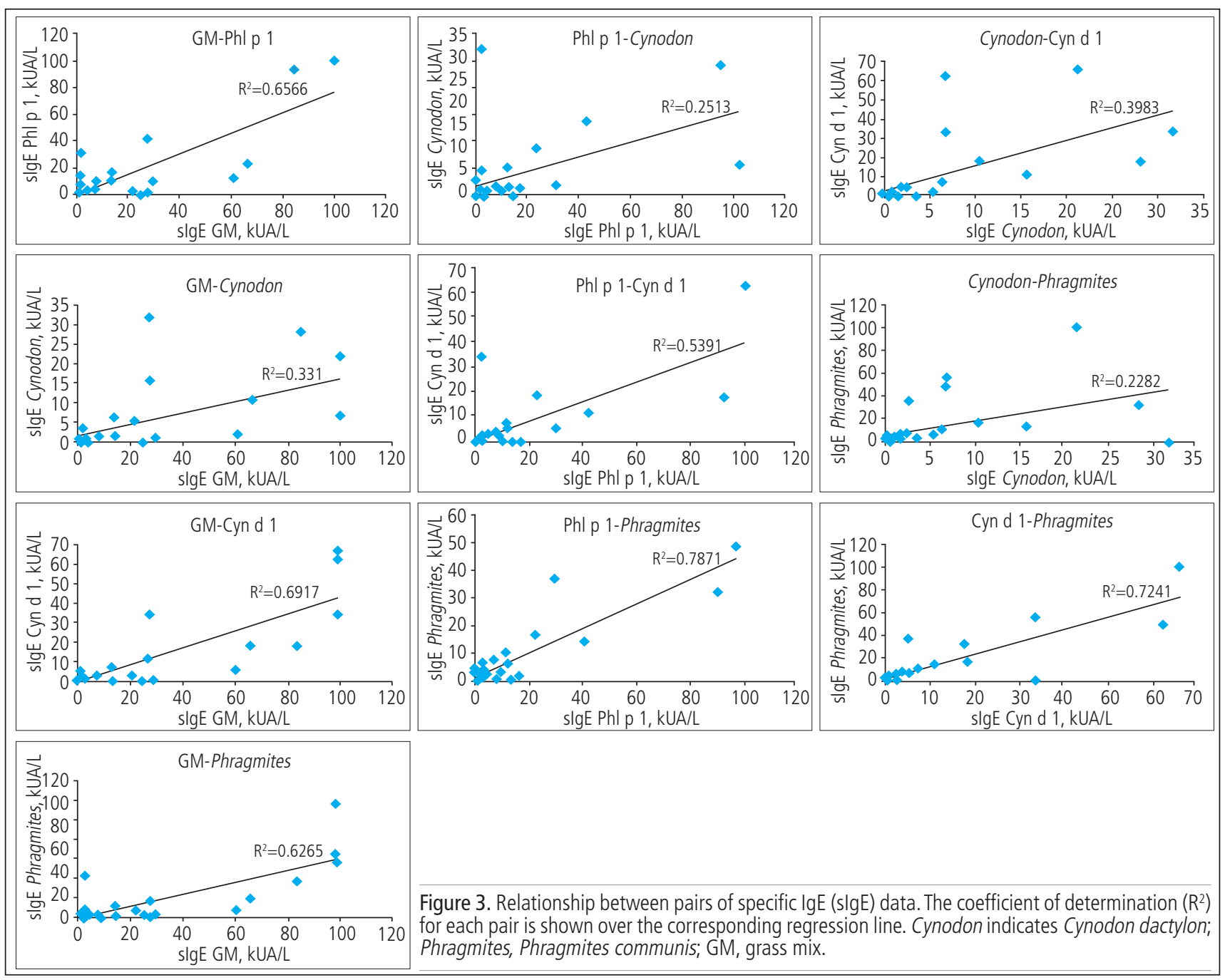




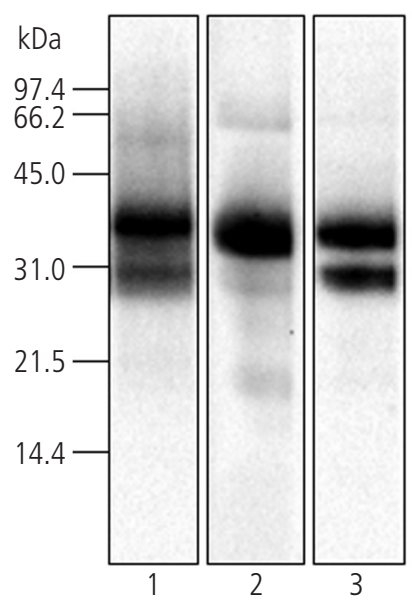

Figure 5. Immunoblot with the pool of sera (dilution 1/5). Fifty micrograms of each extract were run in the solid phase. Lane 1, grass mix; lane 2 , Cynodon dactylon, and lane 3, Phragmites communis.

\section{Inhibition Experiments}

When GM extract was used in the solid phase, no inhibition was observed with the $C$ dactylon or $P$ communis extracts. Conversely, when $C$ dactylon or $P$ communis were used in the solid phase, GM inhibited the binding of the sera similarly to when the inhibition was performed with the same extract. In both cases, the other extract produced an intermediate inhibition (Figure 6).

\section{Quantification of Group 5 Allergens}

The GM extract contained $12.3 \mu \mathrm{g}$ of group 5 allergens $/ \mathrm{mg}$ of lyophilisate. However, no group 5 allergens were detected in the $C$ dactylon or $P$ communis extracts.

\section{Discussion}

We have assessed cross-reactivity between a mixture of 5 grasses (GM) from the homologous sweet grasses group (D glomerata, $F$ elatior, $L$ perenne, $P$ pratense, and $P$ pratensis) and 2 species from different subfamilies: $C$ dactylon (Chloridoideae) and $P$ communis (Arundinoideae). C dactylon and $P$ communis are 2 very abundant subtropical grasses in the study area (Catalonia, northeast Spain). The patients analyzed had positive SPTs to the GM extract. $C$ dactylon and $P$ communis extracts were unable to inhibit IgE binding to the GM extract, but this extract inhibited IgE binding to $C$ dactylon and $P$ communis. Our findings are consistent with the fact that GM is the primary sensitizer in the study population. Asymmetric cross-reactivity between temperate and subtropical grasses has been reported [21] and varies according to the geographic origin of patients.

In areas where different Poaceae subfamilies grow together in the same habitat, it is difficult to determine which species are responsible for triggering symptoms in sensitized patients. The species have similar pollen grain characteristics and are morphologically indistinguishable. To overcome this problem, Frenguelli et al [6] performed a phenology study in Italy and

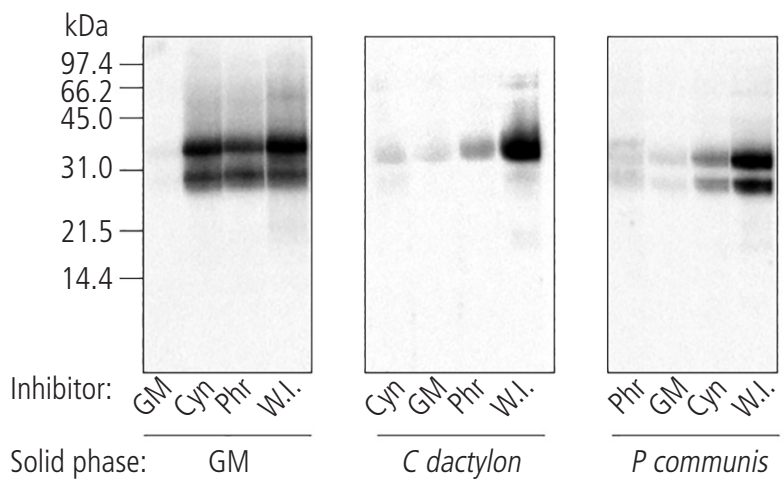

Figure 6. Immunoblot inhibition with the pool of sera (dilution 1/5). Fifty micrograms of each extract were run in the solid phase, the corresponding extracts are indicated at the bottom of figure. The inhibitory extract is indicated in each lane. GM indicates grass mixture, Cyn, Cynodon dactylon, Phr, Phragmites communis, and W.I., without inhibition.

demonstrated that $C$ dactylon flowered later than the other grasses. Knowing that patients with symptoms in summer months (June-July) may be sensitized to $C$ dactylon can aid a correct diagnosis. Comparisons of phenology data with symptoms and the use of component-resolved diagnosis will help to determine individual sensitization profiles and potentially aid in the selection of the most adequate specific immunotherapy.

Eighty percent of the individuals in this study had positive $\operatorname{sgE}$ to $C$ dactylon and $90 \%$ had positive $\operatorname{sg} \mathrm{E}$ to $P$ communis. In the case of group 1 allergens, $92.9 \%$ of the patients had positive results for $\mathrm{Phl} \mathrm{p} 1$ versus $73.3 \%$ for Cyn d 1. Two patients (\#12 and \#14 in Table 1) had high sIgE to $\mathrm{Phl} \mathrm{p} 1$ but negative results for Cyn $\mathrm{d}$ 1. This observation confirms previous reports of immunologic differences between the 2 allergens [17] in terms of recognition of T-cell epitopes $[21,22]$ and in amino acid sequence and 3D structure [13]. In addition, the correlation coefficient $\left(\mathrm{R}^{2}\right)$ between Phl p 1 and Cyn d $1 \mathrm{sIgE}$ values was 0.5 , corroborating the presence of different IgE binding epitopes. $P$ communis sIgE values showed the highest correlation with Phl p 1 sIgE $\left(\mathrm{R}^{2}=0.8\right)$, although the correlation was also high with Cyn d $1\left(\mathrm{R}^{2}=0.7\right)$. Duffort el al [23] developed a monoclonal antibody to quantify Cyn $\mathrm{d} 1$ that also recognized $P$ communis. Both results suggest that Phra 1 shares epitopes with Cyn d 1 and with Phl p 1. Moreover, previously published data show that Phl p 1 has specific epitopes that are not present in group 1 allergens of $C$ dactylon or $P$ communis [18]. Our findings confirm differences in $\operatorname{IgE}$ binding in Phl p 1 and Cyn d 1, probably due to differences in their epitopes. Although the $\mathrm{Phr}$ a 1 sequence is still unknown, our results suggest that it shares more epitopes with Phl p 1 than with Cyn d 1. This hypothesis should be confirmed with purified allergens.

The group 5 allergen in the Poaceae subfamily is a major allergen $[20,24]$, and to date is the only allergen that has been quantified in immunotherapy extracts. However, no authors have described group 5 allergens in $C$ dactylon to date. We confirmed that the group 5 allergen was undetectable in $C$ dactylon with the monoclonal antibody used for the 
quantification of group 5 allergens in sweet grasses (EDQM standard). Although this standard consists of the Phl p 5a isoform, it can be used for the identification and quantification of other Pooideae members. Using the same method, we were also unable to detect group 5 allergens in $P$ communis, suggesting that Phra 5 has different antigenic determinants to group 5 allergens from sweet grasses. Therefore, patients sensitized to $C$ dactylon and/or $P$ communis do not recognize group 5 allergens. Accordingly, it is important to identify the primary sensitizer in each case, as immunotherapy with an extract enriched in group 5 allergens (treatment with a mixture of sweet grasses) may not be effective in patients sensitized to $C$ dactylon or $P$ communis, and moreover it could induce new group 5 sensitizations [25-27].

One of the limitations of this study is the small number of patients included. It would be interesting to study a large group of patients as well as patients selected specifically for sensitization to $C$ dactylon and/or $P$ communis. The second limitation is the absence of clinical results, which are the only way to confirm our in vitro immunological results. It is important to identify primary sensitizers in specific areas to guide choice of immunotherapy, as proposed by Nony et al [28] for Australian patients. In our population, immunotherapy with sweet grasses (Poaceae) would be adequate as all the allergens recognized in $C$ dactylon and $P$ communis were inhibited by the GM extract. A population with primary sensitization to $C$ dactylon and/or $P$ communis could show different crossreactivity patterns and would probably need treatment with the specific species involved.

In summary, $80 \%$ of patients sensitized to grasses were also sensitized to $C$ dactylon and $90 \%$ were sensitized to $P$ communis, but with lower sIgE levels. The GM and $C$ dactylon and $P$ communis extracts have different IgE-binding epitopes, precluding their inclusion in the homologous sweet grasses group. Sensitization to $C$ dactylon and $P$ communis seems to be induced by allergens other than those in sweet grasses. Further clinical studies should be considered to confirm the immunological results.

\section{Acknowledgments}

We thank Raquel Reyes, from the R\&D Department, for her technical work and María Dolores García Arnedo, Jordi García, Jordi Muñoz, Daniel Resina, Aristides Rius and Raul Ramirez for their support.

\section{Funding}

The authors declare that no funding was received for the present study.

\section{Conflicts of Interest}

López-Matas MA, Moya R, and Carnés J are employees of Laboratorios LETI S.L.U. The rest of the authors declare that they have no conflicts of interest.

\section{Previous Presentation}

Part of the results were presented as a poster at the European Academy of Allergy and Clinical Immunology Congress held in June 2015 in Barcelona (Spain).

\section{References}

1. Davies JM. Grass pollen allergens globally: the contribution of subtropical grasses to burden of allergic respiratory diseases. Clin Exp Allergy. 2014;44:790-801.

2. Ling Y, Huang LK, Zhang XQ, Ma X, Liu W, Chen SY, Yan HD. Assessment of genetic diversity of Bermuda grass germplasm from southwest China and Africa by using AFLP markers. Genet Mol Res. 2015;14:1748-56

3. Langdon FN. The origin and distribution of Cynodon dactylon (L.) Pers. The University of Queensland Press. Brisbane. 1954;3:41-4.

4. Feliu A, González-de-Olano D, González E, Rodríguez B, RuizHornillos J, Jimeno $L$, de la Torre $F$ on behalf of the ESPLORA group. A multicenter study of sensitization profiles in an allergic pediatric population in an area with high allergen exposure. J Investig Allergol Clin Immunol. 2013;23:337-44.

5. Armentia A, Martín S, Barrio J, Martín B, García JC, Vega JM, Sánchez A, Fernández P, Corell A. Value of microarray allergen assay in the management of eosinophilic oesophagitis. Allergol Immunopathol (Madr). 2015;43:73-80.

6. Frenguelli $G$, Passalacqua $G$, Bonini $S$, Fiocchi $A$, Incorvaia C, Marcucci F, Tedeschini E, Canonica GW, Frati F. Bridging allergologic and botanical knowledge in seasonal allergy: a role for phenology. Ann Allergy Asthma Immunol. 2010;105:223-7.

7. Spanish plant information system. Available from: http:// www.anthos.es/. Accessed February 2015.

8. Ferrer L, Carnés J, Rojas-Hijazo B, Lopez-Matas MA, Sobrevía MT, Colas C. Assessing degree of flowering implicates multiple Chenopodiaceae/Amaranthaceae species in allergy. Int Arch Allergy Immunol. 2012;158:54-62.

9. Lorenz AR, Lüttkopf $D$, May $S$, Scheurer S, Vieths S. The principle of homologous groups in regulatory affairs of allergen products--a proposal. Int Arch Allergy Immunol. 2009;148(1):1-17.

10. Johansen N, Weber RW, Ipsen H, Barber D, Broge L, Hejl C. Extensive IgE cross-reactivity towards the Pooideae grasses substantiated for a large number of grass-pollen-sensitized subjects. Int Arch Allergy Immunol. 2009; 150:325-4.

11. Gangl K, Niederberger V, Valenta R. Multiple grass mixes as opposed to single grasses for allergen immunotherapy in allergic rhinitis. Clin Exp Allergy. 2013; 43:1202-16.

12. Andersson $\mathrm{K}$, Lidholm J. Characteristics and immunobiology of grass pollen allergens. Int Arch Allergy Immunol. 2003;130:87-107.

13. Heath MD, Swan NJ, Hutchings JW, Mwange JD, Collis J, Skinner MA. Molecular, proteomic and immunological parameters of allergens provide inclusion criteria for new candidates within established grass and tree homologous groups. [Abstract] European Academy of Allergy and Clinical Immunology (EAACI) Congress, Barcelona, Spain, June 2015.

14. Allergen Nomenclature WHO/IUIS Allergen Nomenclature Sub-Committee. Available from: http://www.allergen.org/. Accessed June 2015.

15. Allergome: The platform for Allergen Knowledge. Available from: http://www.allergome.org/. Accessed June 2015.

16. Weber RW. Cross-reactivity of pollen allergens: impact on allergen immunotherapy. Ann Allergy Asthma Immunol. 2007:99:203-12.

17. Duffort O, Quintana J, Ipsen H, Barber D, Polo F. Antigenic similarity among group 1 allergens from grasses and 
quantitation ELISA using monoclonal antibodies to $\mathrm{Phl} p 1$. Int Arch Allergy Immunol. 2008;145:283-90.

18. González RM, Cortés C, Conde J, Negro JM, Rodriguez J, Tursi A, Wüthrich B, Carreira J. Cross-reactivity among five major pollen allergens. Ann Allergy. 1987;59:149-54.

19. Niederberger $V$, Laffer S, Fröschl R, Kraft D, Rumpold H, Kapiotis $S$, Valenta R, Spitzauer S. IgE antibodies to recombinant pollen allergens (Phl p 1, Phl p 2, Phl p 5, and Bet v 2) account for a high percentage of grass pollen-specific IgE. J Allergy Clin Immunol. 1998;101:258-64.

20. Van Ree R, Driessen MN, Van Leeuwen WA, Stapel SO, Aalberse RC. Variability of crossreactivity of IgE antibodies to group I and $V$ allergens in eight grass pollen species. Clin Exp Allergy. 1992;22:611-7.

21. Davies JM. Grass pollen allergens globally: the contribution of subtropical grasses to burden of allergic respiratory diseases. Clin Exp Allergy. 2014; 44:790-801

22. Eusebius NP, Papalia L, Suphioglu C, McLellana SC, Varneyc M, Rolland JM, O'Hehira RE. Oligoclonal analysis of the atopic T cell response to the group 1 allergen of Cynodon dactylon (bermuda grass) pollen: pre- and post-allergen-specific immunotherapy. Int Arch Allergy Immunol. 2002;127:234-44.

23. Duffort O, Calabozo B, Gonzalez R, Carpizo JA, Barber D, Polo F. Monoclonal antibody-based ELISA to quantify the major allergen of Cynodon dactylon (Bermuda grass) pollen, Cyn d 1. Int Arch Allergy Immunol. 2004;135:277-83.

24. Laffer $S$, Spitzauer $S$, Susani M, Pairleitner $H$, Schweiger $C$, Grönlund H, Menz G, Pauli G, Ishii T, Nolte H, Ebner C, Sehon $A H$, Kraft D, Eichler HG, Valenta R. Comparison of recombinant timothy grass pollen allergens with natural extract for diagnosis of grass pollen allergy in different populations. J Allergy Clin Immunol. 1996;98:652-8.
25. Sastre J, Raulf-Heimsoth $M$, Rihs HP, Fernández-Nieto $M$, Barber D, Lombardero M, Martín S, Quirce S. IgE reactivity to latex allergens among sensitized healthcare workers before and after immunotherapy with latex. Allergy. 2006;61:20610.

26. Tavares B, Rordigues F, Pereira C, Loureiro G, Chieira C. Development of new $\mathrm{lgE}$ specificities to hymenoptera allergens during venom-specific immunotherapy. Eur Ann Allergy Clin Immunol. 2005;37:171-6.

27. Movérare R, Elfman L, Vesterinen E, Metso T, Haahtela T. Development of new lgE specificities to allergenic components in birch pollen extract during specific immunotherapy studied with immunoblotting and Pharmacia CAP System. Allergy. 2002; 57:423-30.

28. Nony E, Timbrell V, Hrabina M, Boutron M, Solley G, Moingeon P, Davies JM. Specific IgE recognition of pollen allergens from subtropic grasses in patients from the subtropics. Ann Allergy Asthma Immunol. 2015;114:214-20.

- Manuscript received October 27, 2015; accepted for publication, December 29, 2015.

\section{Jerónimo Carnés}

Research \& Development

Laboratorios LETI, S.L.U.

Calle del Sol $n^{\circ} 5$

28760 Tres Cantos, Madrid, Spain

E-mail: jcarnes@leti.com 